\title{
Effects of moderate fat intake with different $n-3$ fatty acid sources and $n-6 / n-3$ ratios on serum and structural lipids in rats
}

\author{
L Frémont, MT Gozzelino, T Hojjat \\ INRA, laboratoire de nutrition et sécurité alimentaire, 78352 Jouy-en-Josas cedex, France
}

(Received 16 March 1995; accepted 30 May 1995)

\begin{abstract}
Summary - The aim of this study was to compare the effects of dietary polyunsaturated fatty acids (PUFA) on serum and membrane lipids in rats fed diets containing moderate levels of fats $(6 \%$ by weight). Control rats received enough PUFA to prevent any deficiency. Experimental rats were fed linseed oil, salmon oil, or sunflower oil. After 8 weeks of feeding, fasting serum triacylglycerol and cholesterol levels were not altered in the linseed oil group. In contrast, in the salmon oil group, serum cholesterol was lowered by $58 \%(P<0.05)$ and the specific binding of heterologous LDL to liver plasma membrane was reduced by $31 \%(P<0.05)$. Unexpectedly, serum triacylglycerol levels were not significantly lowered $(-14 \%)$ whereas they decreased $(-32 \% ; P<0.05)$ in the sunflower oil group. Oleic acid, which has a stimulating effect on triacylglycerol synthesis and secretion, was less incorporated in serum and liver plasma membrane in rats fed sunflower oil than in rats fed other dietary lipids. This finding suggests that the effect of dietary sunflower oil was partly mediated by the reduction of oleic acid available for triacylglycerol synthesis.
\end{abstract}

polyunsaturated fatty acid ( $n-6, n-3)$ / triacylglycerol / cholesterol / LDL receptor activity / liver plasma membrane

Résumé - Effets de l'ingestion de quantités modérées de lipides différant par l'origine des acides gras de la série n-3 et par le rapport n-6/n-3 sur les lipides sériques et structuraux chez le rat. Ce travail a pour but de comparer les effets des acides gras polyinsaturés (AGPI) sur les lipides sériques et membranaires chez des rats ayant reçu des régimes contenant une quantité modérée de lipides (6\% de l'aliment). Les rats témoins ont reçu les quantités d'AGPI requises pour éviter la carence. Les rats expérimentaux ont reçu i) de l'huile de lin, ii) de l'huile de saumon, iii) de l'huile de tournesol. Après $8 \mathrm{sem}$ de régime, les concentrations des triglycérides et du cholestérol du sérum à jeun n'ont pas été modifiées dans le groupe «huile de lin». En revanche, dans le groupe "huile de saumon" la concentration du cholestérol sérique a été réduite de $58 \%(\mathrm{P}<0,05)$ et la fixation spécifique de $L D L$ hétérologues sur la membrane plasmique du foie a été réduite de $31 \%(\mathrm{P}<0,05)$. De façon inattendue, les triglycérides du sérum n'ont diminué que de $14 \%$ (non significatif) alors que, dans le groupe "huile de tournesol", une réduction de $32 \%(P<0,05)$ a été observée. Dans le sérum et la membrane plasmique du foie, l'acide oléique, qui a la capacité d'augmenter la synthèse et la sécrétion des triglycérides, 
était incorporé en proportions plus faibles chez les rats "huile de tournesol» que chez les rats des autres groupes. Cette observation suggère que l'effet de l'huile de tournesol est en partie dû à la diminution de la quantité d'acide oléique disponible pour la synthèse des triglycérides.

acide gras polyinsaturé (n-6, n-3) / triglycéride / cholestérol / activité récepteur LDL / membrane plasmique du foie

\section{INTRODUCTION}

The hypolipidemic effect of dietary polyunsaturated fatty acids (PUFA) involves several mechanisms. Some of these are likely related to changes in the fatty acid composition of cellular membranes. Indeed, it is well known that alterations of membrane phospholipids affect many biological functions (Goodnight et al, 1982; Clandinin et al, 1985; Wahle, 1983; Murphy, 1990).

The cellular pool of PUFA available for membrane and esterified lipid synthesis is controlled by the extent of competitive inhibitions between the $n-6$ and $n-3$ series for the enzymatic bioconversion system (Brenner and Peluffo, 1969; Blond et al, 1978) and by the existence of exchanges and interactions between fatty acids (Holman, 1986). Accordingly, the biological effects of PUFA are related to the $n-6 / n-3$ ratio of the intake, to the dietary source which provides precursors and (or) derivatives, and to the proportion of other fatty acids. Fish oils, which contain eicosapentaenoic acid (20:5n-3) and docosahexaenoic acid (22:6n-3), are very efficient in reducing serum triacylglycerol levels in rats (Wong et al, 1982) and humans (Harris et al, 1983). They also reduce serum cholesterol levels in rats (Durand et al, 1978; Balasubramaniam et al, 1985) and humans (Harris et al, 1983). Several vegetable oils contain the parent $\alpha$-linolenic acid (18:3n3) but in humans, their biological effects are much lower than those of long-chain derivatives (Sanders and Roshani, 1983; Budowski and Crawford, 1985; Cunnane et al, 1991). The hypolipidemic effects of $n-6$ PUFA differ from those of $n-3$ PUFA. Actually, vegetable oils rich in linoleic acid (18:2n-6) lower serum cholesterol but not triacylglycerols in humans (Harris et al, 1983) and have little or no effect in rats (Balasubramaniam et al, 1985; Chautan et al, 1990).

In experiments using model animals, the effects of diets containing PUFA are often compared with the effects of standard lipidpoor diets or diets which induce hyperlipidemia by being overenriched in saturated fatty acids and (or) cholesterol. This can explain discrepancies between data. Therefore, the present study was carried out on rats fed moderate levels of fats containing less than $20 \%$ of saturated fatty acids without added cholesterol.

We determined the cholesterol and triacylglycerol contents of the serum since these parameters specifically respond to dietary $n-6$ or n-3 PUFA. We therefore compared the effects of 4 types of diets which differed mainly in their PUFA content and 18:2 to $n-3$ (precursor and derivatives) ratio. Under these conditions, we examined whether the response of circulating lipids was associated with changes in the fatty acid composition of structural lipids. We analyzed liver plasma membrane and lymphocyte phospholipids, which are both altered by changes in dietary lipids (Clandinin et al, 1985). We also determined the specific binding activity of the liver plasma membrane from the various dietary groups for a defined type of LDL.

\section{MATERIALS AND METHODS}

\section{Animals and diets}

Male Wistar rats (IFFA, CREDO, France) bred in our laboratory were randomly distributed into 
4 groups of 12 rats just after weaning ( $21 \mathrm{~d}$ old). During the following 8 weeks, rats were fed ad libitum purified diets, containing $6 \%$ by weight (about $13 \%$ of total calories) of different types of lipids.

A control group received a mixture of peanut oil and rapeseed oil providing the required lev-

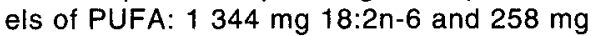
$18: 3 n-3 / 100 \mathrm{~g}$ diet (PR diet; $n-6 / n-3=5.2$ ). For the rat, the minimum $\alpha$-linolenic and linoleic acid intake should be $200 \mathrm{mg}$ and $1200 \mathrm{mg} / 100 \mathrm{~g}$ diet respectively (Bourre et al, 1989).

The 3 experimental groups received: 1) a mixture of peanut oil and linseed oil, which provided almost equivalent amounts of precursors (LN diet; 18:2n-6/18:3n-3 = 0.93); 2) sunflower oil, which provided the precursor 18:2 n-6 (SF diet; $18: 2 n-6 / 18: 3 n-3=664$ ); or 3) salmon oil, which provided long-chain n-3 PUFA (SM diet; $18: 2 n-6 / n-3=0.11)$. The fatty acid composition of the diets is shown in table $\mathrm{l}$.

The other components of diets were (w/w) $22 \%$ casein, $43.2 \%$ cornstarch, $21.6 \%$ sucrose, $4 \%$ mineral mixture, $1 \%$ vitamin mixture, $2 \%$ cellulose, and $0.16 \%$ methionine.

After an overnight fast, the rats were killed by decapitation without anesthesia and exsanguinated. The liver and spleen were removed. The serum obtained by centrifugation at lowspeed was protected by adding EDTA ( $1 \mathrm{mg} / \mathrm{mL}$ ) and sodium azide $(0.02 \%)$. The serum and liver were stored at $-80^{\circ} \mathrm{C}$, whereas the spleen was immediately treated. Samples from each dietary group were randomly pooled 3 by 3 into 4 subgroups.

Table I. Fatty acid composition of control and experimental diets.

\begin{tabular}{|c|c|c|c|c|c|c|c|c|}
\hline \multirow[t]{2}{*}{ Fatty acid } & \multicolumn{2}{|c|}{ SF diet } & \multicolumn{2}{|c|}{ PR (control) diet } & \multicolumn{2}{|c|}{$L N$ diet } & \multicolumn{2}{|c|}{$S M$ diet a } \\
\hline & $w t \%$ & $\underset{\text { diet }}{m g / 100 \mathrm{~g}}$ & $W t \%$ & $\begin{array}{c}m g / 100 \mathrm{~g} \\
\text { diet }\end{array}$ & $w t \%$ & $\underset{\text { diet }}{m g / 100 g}$ & $w t \%$ & $\underset{\text { diet }}{m g / 100 \mathrm{~g}}$ \\
\hline 14:0 & & & & & & & 7.2 & \\
\hline $16: 0$ & 7.2 & & 8.2 & & 8.7 & & 15.9 & \\
\hline $16: 1 n-7$ & & & 0.2 & & & & 11.3 & \\
\hline 18:0 & 5.2 & & 2.9 & & 3.5 & & 2.9 & \\
\hline $18: 1 n-9$ & 20.3 & 1218 & 58.6 & 3516 & 42.0 & 2520 & 15.5 & 930 \\
\hline $18: 1 n-7$ & 0.9 & & 2.2 & & 1.3 & & 4.1 & \\
\hline $18: 2 n-6$ & 66.4 & 3984 & 22.4 & 1344 & 21.1 & 1266 & 2.7 & 162 \\
\hline $18: 3 n-3$ & 0.1 & 6 & 4.3 & 258 & 22.6 & 1356 & 1.1 & 66 \\
\hline $18: 4 n-3$ & & & & & & & 2.9 & 174 \\
\hline $20: 1 n-9$ & & & 1.2 & & 0.8 & & 5.8 & \\
\hline $20: 4 n-6$ & & & & & & & 0.9 & \\
\hline $20: 5 n-3$ & & & & & & & 13.9 & 834 \\
\hline $22: 5 n-3$ & & & & & & & 2.8 & \\
\hline $22: 6 n-3$ & & & & & & & 13.1 & 786 \\
\hline Saturated & 12.4 & & 11.1 & & 12.1 & & 18.8 & \\
\hline Monounsaturated & 21.2 & & 62.2 & & 44.2 & & 36.7 & \\
\hline$n-6$ & 66.4 & & 22.4 & & 21.1 & & 3.6 & \\
\hline$n-3$ & 0.1 & & 4.3 & & 22.6 & & 33.7 & \\
\hline U $\mathrm{I}^{\mathrm{b}}$ & 12.5 & & 10.8 & & 12.7 & & 11.9 & \\
\hline
\end{tabular}

a Containing less than $0.05 \%$ cholesterol; $b$ unsaturation index (UI) is $\Sigma[a \times b] / S$ where $a$ is the relative percentage of each unsaturated fatty acid; $b$ is the number of double bonds for that particular fatty acid; $S$ is the percentage of total saturated fatty acids. 


\section{Preparation of cells and subcellular fractions}

The spleens were rinsed twice with phosphatebuffered saline (PBS) pH 7.5, gently minced in the same buffer with a loosely fitting glass homogenizer and filtered through nylon gauze. All steps were conducted at room temperature. After 2 washes, the $5 \mathrm{~mL}$ cell suspension was loaded onto a layer of a Ficoll solution (Lymphocyte Separation Medium MSL 2000; $d=1.077$; Eurobio, Les Ulis, France) and centrifuged at $500 \mathrm{~g}$ for $15 \mathrm{~min}$. Mononuclear cells (mainly lymphocytes) floated at the interface as a white layer. They were collected and recentrifuged. Finally, the volume was adjusted to $1.5 \mathrm{~mL}$ with PBS and stored at $-80^{\circ} \mathrm{C}$.

Pooled samples ( $2 \mathrm{~g}$ per rat) of thawed livers from each subgroup were immersed in $20 \mathrm{vol}$ of ice-cold buffer ( $250 \mathrm{mM}$ sucrose, $5 \mathrm{mM}$ HEPES, $0.5 \mathrm{mM}$ EGTA pH 7.4). They were chopped with scissors and homogenized at $4{ }^{\circ} \mathrm{C}$ using a Potter Elvehjem homogenizer. The protein of the liver homogenate was assayed according to Bradford (1976) using the Biorad Protein Assay (Biorad, Richmond, CA).

A plasma membrane (PM) enriched fraction was obtained from the liver homogenate according to the procedure of Epping and Bygrave (1984) using a discontinuous density gradient of Percoll (Pharmacia, Uppsala, Sweden), as previously described (Frémont et al, 1993). The plasma membrane enriched pellet was suspended in the HEPES buffer without sucrose and stored at $-80^{\circ} \mathrm{C}$.

\section{Lipid analysis}

Serum triacylglycerol and cholesterol concentrations were measured using enzymatic colorimetric tests (644200 and 1442341 Boehringer Mannheim, Meylan, France). The HDL-cholesterol $(\mathrm{HDL}-\mathrm{C})$ was determined after the precipitation of VLDL and LDL by the dextran sulfate$\mathrm{Mg}^{2+}$ procedure of Warnick et al (1979) adapted for rat serum (Sjoblom and Eklund, 1989).

Lipids were extracted from the serum, lymphocyte suspension and liver PM with chloroform/methanol (2:1) according to Folch et al (1957) using a Polytron (Kinematica PT 1200) for $7 \mathrm{~s}$.

Lymphocyte phospholipids (PL) were separated from neutral lipids and glycolipids on a sil- ica cartridge (SEP-PACK, Waters Associates, Milford, MA) by successively eluting with chloroform, acetone and methanol (Juaneda and Rocquelin, 1985).

The fatty acid composition of serum total lipids, liver PM and lymphocyte PL was determined by gas-liquid chromatography of the fatty acid methyl esters obtained after transmethylation. The Carlo Erba model 4180 (Milan, Italy) chromatograph included an automatic injector on the column, a flame ionization detector and a CP wax $52 \mathrm{CB}$ (carbowax $20 \mathrm{M}$ ) bonded fused silica capillary column ( $50 \mathrm{~m} \times 0.2 \mathrm{~mm}$ internal diameter). The assays were carried out with programmed oven temperature rises of $3^{\circ} \mathrm{C} / \mathrm{min}$ from $54^{\circ} \mathrm{C}$ to $200^{\circ} \mathrm{C}$. Hydrogen was the carrier gas at a pressure of 0.8 bar. Peak areas were measured with an integrator connected to a microcomputer which expressed the data automatically. Peaks were identified by comparing their equivalent chain lengths with those of authentic fatty acid methyl esters.

\section{$L D L$ receptor activity}

Receptors were assayed by binding with LDL obtained from standard-fed pigs reared in our institute. We estimated that porcine LDL are suitable for testing the binding capacity of rat liver membranes because the domains of pig and rat apolipoprotein B 100, which bind to the LDL receptor, show a high degree of homology (Law and Scott, 1990).

The LDL fraction (d $1.018-1.063 \mathrm{~g} / \mathrm{mL}$ ) was obtained by sequential ultracentrifugation according to Havel et al (1955) using a Beckman L 8-55 $M$ centrifuge (Beckman Instruments, Palo Alto CA) equipped with a Beckman 50 Ti rotor at $145000 \mathrm{~g}$ and $10^{\circ} \mathrm{C}$. Serum was first centrifuged for $18 \mathrm{~h}$ at $d=1.018 \mathrm{~g} / \mathrm{mL}$ to remove floating VLDL. The LDL fraction was further isolated after a $24 \mathrm{~h}$ run at $d=1.063 \mathrm{~g} / \mathrm{mL}$; it was recentrifuged at the same density, dialyzed overnight at $4^{\circ} \mathrm{C}$ against $50 \mathrm{mM}$ EDTA pH 8 and sterilized through a $0.22 \mu \mathrm{m}$ Millipore filter. The fatty acid composition was (weight \%): $29 \%$ saturated; $21 \% 18: 1 n$ 9; 40\% 18:2n-6; 7\% 20:4n-6; 3\% n-3 PUFA).

The $L D L$ receptor activity of rat liver $P M$ was determined by a dot-blot technique derived from that described by Roach et al (1987b) and by Maggi and Catapano (1987) using colloidal goldLDL conjugates. A $5 \mathrm{~mL}$ volume of a colloidal 
gold solution (Aurobeads RPN 477, $15 \mathrm{~nm}$, Amersham, Les Ulis, France) was rapidly added to $\mathrm{LDL}$ diluted to $0.5 \mathrm{~mL}$ ( $30 \mu \mathrm{g}$ of protein) in deionized water. After agitating on a Vortex mixer for at least $1 \mathrm{~min}$, the mixture was centrifuged at 20 $000 \mathrm{~g}$ for $1 \mathrm{~h}$, against a $35 \%$ (w/v) sucrose cushion. The pelleted colloidal gold-LDL conjugates were suspended in $2 \mathrm{~mL}$ of $50 \mathrm{mM}$ EDTA pH 8 and dialyzed overnight in $0.15 \mathrm{M} \mathrm{NaCl}, 1 \mathrm{mM}$ EDTA pH 7.5 at $4^{\circ} \mathrm{C}$.

The thawed preparation of liver PM was centrifuged at $25000 \mathrm{~g}$ (Airfuge Beckman) so as to sediment the membranes. The pellet was solubilized in $2 \mathrm{mM} \mathrm{CaCl}_{2}, 1 \mathrm{mM}$ phenylmethylsulfonyl fluoride, $40 \mathrm{mM}$ octylthioglucoside. The solution was agitated on a Vortex mixer, flushed several times through a 26 -gauge needle and centrifuged $(80000 \mathrm{~g})$ for $30 \mathrm{~min}$ at $4^{\circ} \mathrm{C}$ so as to eliminate insoluble particles. The volume was adjusted to obtain a final protein concentration of $8-12 \mathrm{mg} / \mathrm{mL}$.

The dot-blot assays were carried out using a manifold apparatus (Biorad, Richmond, CA) equipped with cellulose nitrate sheets $(0.45 \mu \mathrm{m}$, BA 85; Schleicher and Schuell, Dassel, Germany). The nitrocellulose was briefly wetted with deionized water and placed in the apparatus. The solubilized membranes were diluted in membrane buffer to $0.3 \mathrm{mg} / \mathrm{mL}$ and aliquots were applied in wells (3-10 $\mu \mathrm{g}$ of protein). The wells were washed with $150 \mu \mathrm{L}$ of membrane buffer and the unbound sites of the nitrocellulose were saturated by incubating for $90 \mathrm{~min}$ at room temperature in $200 \mu \mathrm{L}$ of $60 \mathrm{mM}$ Tris- $\mathrm{HCl} \mathrm{pH} 8$ containing $25 \mathrm{mM} \mathrm{NaCl}, 2 \mathrm{mM} \mathrm{CaCl}{ }_{2}$ and $6 \% \mathrm{BSA}$ $(w / v)$. The blots were incubated for $1 \mathrm{~h}$ at room temperature in the presence of $15 \mu \mathrm{g} / \mathrm{mL}$ of col- loidal gold-LDL conjugates in $60 \mathrm{mM}$ Tris $\mathrm{HCl}$ pH 8 containing $25 \mathrm{mM} \mathrm{NaCl}, 2 \mathrm{mM} \mathrm{CaCl}_{2}, 2 \%$ BSA (total LDL binding). Some incubations contained a 50 -fold excess of unlabelled LDL for estimating non-specific LDL binding. The blots were rinsed twice for $10 \mathrm{~min}$ with the incubation buffer containing $1 \%$ BSA. The sheets were washed with copious amounts of deionized water and dried. A Shimadzu (Kyoto, Japan) densitometer was used at $620 \mathrm{~nm}$ to visualize binding. The LDL receptor activity was expressed as integrator peaks (height in $\mathrm{mm}$ ).

\section{Statistical analysis}

Data are presented as means \pm SE. Differences between dietary groups were determined by analysis of variance (ANOVA). Comparisons were made using Fisher's least significance difference test at the $P<0.05$ level of significance.

\section{RESULTS}

There were no significant differences between groups for final body weights.

\section{Serum lipids}

The concentrations of serum triacylglycerol from the $L N$ group were similar to

Table II. Serum lipids after 8 weeks of dietary treatment *.

\begin{tabular}{lcccc} 
Fatty acid & $\begin{array}{c}\text { SF diet } \\
(\mu \mathrm{mol} / \mathrm{mL})\end{array}$ & $\begin{array}{c}\text { PR (control) diet } \\
(\mu \mathrm{mol} / \mathrm{mL})\end{array}$ & $\begin{array}{c}L N \text { diet } \\
(\mu \mathrm{mol} / \mathrm{mL})\end{array}$ & $\begin{array}{c}S M \text { diet } \\
(\mu \mathrm{mol} / \mathrm{mL})\end{array}$ \\
\hline Triacylglycerols & $0.92 \pm 0.09^{\mathrm{b}}$ & $1.35 \pm 0.05^{\mathrm{ac}}$ & $1.37 \pm 0.09^{\mathrm{ac}}$ & $1.16 \pm 0.04^{\mathrm{c}}$ \\
Total cholesterol & $1.35 \pm 0.11^{\mathrm{b}}$ & $1.62 \pm 0.07^{\mathrm{a}}$ & $1.44 \pm 0.09^{\mathrm{ab}}$ & $0.68 \pm 0.04^{\mathrm{c}}$ \\
HDL cholesterol & $1.17 \pm 0.08^{\mathrm{ab}}$ & $1.33 \pm 0.07^{\mathrm{a}}$ & $1.15 \pm 0.07^{\mathrm{a}}$ & $0.52 \pm 0.04^{\mathrm{c}}$ \\
HDL chol/total chol & $0.86 \pm 0.01^{\mathrm{b}}$ & $0.82 \pm 0.01^{\mathrm{ab}}$ & $0.80 \pm 0.02^{\mathrm{a}}$ & $0.77 \pm 0.02^{\mathrm{a}}$
\end{tabular}

\footnotetext{
* Mean value of 4 pooled samples ( 3 animals per pool) \pm SE. Means with no common superscript are significantly different at $P<0.05$.
} 
those from the control group despite a much higher 18:3n-3 intake (table II). By contrast, salmon oil feeding decreased values by $14 \%$ (not significant). The lowest levels were obtained with sunflower oil where the difference reached $32 \%(P<$ 0.05).

The changes affecting serum cholesterol did not follow those affecting triacylglycerols. The $\mathrm{LN}$ diet had a tendency (not significant) to lower serum total cholesterol whereas the SM diet was very efficient in decreasing both total cholesterol $(-58 \%$; $P<0.05)$ and HDL-cholesterol $(-61 \% ; P<$ $0.05)$. The SF diet had little effect since total cholesterol was reduced by $17 \%(P<0.05)$ and HDL-cholesterol by $12 \%$ (not significant).

\section{Fatty acid composition}

The effects of diet on the fatty acid composition of serum total lipids, liver PM lipids and lymphocyte phospholipids are shown

Table III. Fatty acid composition of serum lipids after 8 weeks of dietary treatment *.

\begin{tabular}{|c|c|c|c|c|}
\hline Fatty acid & $\begin{array}{c}\text { SF diet } \\
\text { (\% of total) }\end{array}$ & $\begin{array}{c}P R \text { (control) diet } \\
\text { (\% of total) }\end{array}$ & $\begin{array}{c}L N \text { diet } \\
\text { (\% of total) }\end{array}$ & $\begin{array}{c}\text { SM diet } \\
(\% \text { of total) }\end{array}$ \\
\hline $16: 0$ & $19.6 \pm 0.9^{a}$ & $18.7 \pm 0.2^{\mathrm{a}}$ & $22.8 \pm 0.9^{b}$ & $23.4 \pm 0.8^{b}$ \\
\hline $16: 1 n-9$ & $0.4 \pm 0.1$ & $0.4 \pm 0.1$ & $0.6 \pm 0.1$ & $0.5 \pm 0.1$ \\
\hline $16: 1 n-7$ & $1.0 \pm 0.1^{a}$ & $1.4 \pm 0.1^{\mathrm{a}}$ & $2.0 \pm 0.2^{b}$ & $3.3 \pm 0.1^{c}$ \\
\hline $18: 0$ & $13.0 \pm 0.3^{a}$ & $11.9 \pm 0.4^{a}$ & $10.6 \pm 0.3^{b}$ & $9.4 \pm 0.4^{b}$ \\
\hline $18: 1 n-9$ & $8.9 \pm 0.8^{c}$ & $20.2 \pm 0.9 a$ & $16.0 \pm 0.8^{b}$ & $15.8 \pm 0.8^{b}$ \\
\hline $18: 1 n-7$ & $2.1 \pm 0.2^{b}$ & $2.7 \pm 0.1^{\mathrm{a}}$ & $2.7 \pm 0.1^{\mathrm{a}}$ & $3.0 \pm 0.2^{\mathrm{a}}$ \\
\hline $18: 2 n-6$ & $18.5 \pm 0.4^{d}$ & $11.5 \pm 0.2^{\mathrm{a}}$ & $13.3 \pm 0.2^{b}$ & $5.2 \pm 0.2^{c}$ \\
\hline $18: 3 n-3$ & $0.1 \pm 0.04^{c}$ & $0.7 \pm 0.02^{\mathrm{a}}$ & $2.8 \pm 0.1^{b}$ & $0.3 \pm 0.1^{c}$ \\
\hline $20: 0$ & $0.1 \pm 0.01$ & $0.2 \pm 0.05$ & $0.1 \pm 0.04$ & ND \\
\hline $20: 1 n-9$ & $0.3 \pm 0.02^{b}$ & $0.2 \pm 0.01^{a}$ & ND & $0.4 \pm 0.1^{b}$ \\
\hline $20: 3 n-9$ & $0.2 \pm 0.04^{\mathrm{ab}}$ & $0.2 \pm 0.02^{a}$ & $0.6 \pm 0.1^{\mathrm{ab}}$ & $0.7 \pm 0.3^{b}$ \\
\hline $20: 3 n-6$ & $0.2 \pm 0.01^{c}$ & $0.3 \pm 0.01^{\mathrm{ac}}$ & $0.5 \pm 0.02^{b}$ & $0.3 \pm 0.1^{\mathrm{a}}$ \\
\hline $20: 4 n-6$ & $30.5 \pm 1.2^{d}$ & $26.0 \pm 0.6^{\mathrm{a}}$ & $15.1 \pm 0.6^{\mathrm{b}}$ & $9.0 \pm 0.7^{c}$ \\
\hline $20: 5 n-3$ & $0.3 \pm 0.1^{a}$ & $0.5 \pm 0.04^{a}$ & $2.8 \pm 0.1^{b}$ & $9.5 \pm 0.6^{c}$ \\
\hline $22: 0$ & $0.6 \pm 0.1^{c}$ & $0.1 \pm 0.02^{a}$ & $1.2 \pm 0.2^{\mathrm{b}}$ & ND \\
\hline $22: 4 n-6$ & $0.6 \pm 0.2^{\mathrm{ab}}$ & $0.2 \pm 0.03^{a}$ & $0.5 \pm 0.02^{\mathrm{ab}}$ & $0.9 \pm 0.3^{b}$ \\
\hline $22: 5 n-6$ & $1.8 \pm 0.05$ & $1.0 \pm 0.1$ & $1.6 \pm 0.3$ & $1.7 \pm 0.5$ \\
\hline $22: 5 n-3$ & ND & $0.4 \pm 0.01^{a}$ & $1.1 \pm 0.02^{b}$ & $2.0 \pm 0.1^{c}$ \\
\hline $22: 6 n-3$ & $1.3 \pm 0.1^{b}$ & $3.2 \pm 0.1^{\mathrm{a}}$ & $5.6 \pm 0.4^{a}$ & $14.4 \pm 1.8^{c}$ \\
\hline 24:0 & $0.3 \pm 0.03^{\mathrm{ab}}$ & $0.3 \pm 0.02^{\mathrm{ab}}$ & $0.3 \pm 0.02^{a}$ & $0.2 \pm 0.03^{b}$ \\
\hline Saturated & $33.6 \pm 1.1^{\mathrm{ab}}$ & $31.2 \pm 0.8^{a}$ & $34.9 \pm 1.1^{\mathrm{b}}$ & $33.0 \pm 1^{\mathrm{ab}}$ \\
\hline Monounsaturated & $12.8 \pm 0.9^{c}$ & $24.8 \pm 1.1^{a}$ & $21.2 \pm 1.1^{b}$ & $22.9 \pm 1.1^{\mathrm{ab}}$ \\
\hline$n-6$ & $51.6 \pm 1.2^{\mathrm{d}}$ & $39.0 \pm 0.9 \mathrm{a}$ & $30.9 \pm 0.7^{b}$ & $17.1 \pm 0.5^{\mathrm{c}}$ \\
\hline$n-3$ & $1.7 \pm 0.1^{d}$ & $4.8 \pm 0.1^{\mathrm{a}}$ & $12.3 \pm 0.3^{b}$ & $26.2 \pm 1.3 c$ \\
\hline$(n-6)+(n-3)$ & $53.3 \pm 1.3^{\mathrm{b}}$ & $43.8 \pm 1.0^{a}$ & $43.3 \pm 1.0^{a}$ & $43.3 \pm 1.8^{\mathrm{ac}}$ \\
\hline$n-6 / n-3$ & 30.3 & 8.1 & 2.5 & 0.7 \\
\hline
\end{tabular}

* Abbreviations are the same as in table II. ND = not detected. 
Table IV. Fatty acid composition of liver plasma membrane lipids after 8 weeks of dietary treatment *.

\begin{tabular}{|c|c|c|c|c|}
\hline Fatty acid & $\begin{array}{c}\text { SF diet } \\
\text { (\% of total) }\end{array}$ & $\begin{array}{l}P R \text { (control) diet } \\
\text { (\% of total) }\end{array}$ & $\begin{array}{l}L N \text { diet } \\
(\% \text { of total) }\end{array}$ & $\begin{array}{c}\text { SM diet } \\
(\% \text { of total) }\end{array}$ \\
\hline $16: 0$ & $20.9 \pm 0.3^{a}$ & $21.6 \pm 0.4^{a}$ & $24.5 \pm 0.7^{b}$ & $27.5 \pm 0.5^{c}$ \\
\hline $16: 1 n-9$ & $0.5 \pm 0.1$ & $0.6 \pm 0.2$ & $0.7 \pm 0.1$ & $0.4 \pm 0.02$ \\
\hline $16: 1 n-7$ & $1.0 \pm 0.1^{\mathrm{a}}$ & $1.3 \pm 0.3^{a}$ & $1.8 \pm 0.1^{b}$ & $2.4 \pm 0.02^{\mathrm{c}}$ \\
\hline 18:0 & $21.6 \pm 0.2^{a}$ & $21.4 \pm 0.9 \mathrm{a}$ & $17.2 \pm 0.3^{b}$ & $19.5 \pm 0.4^{c}$ \\
\hline $18: 1 n-9$ & $7.1 \pm 0.5^{b}$ & $11.4 \pm 0.6^{a}$ & $12.6 \pm 0.4^{a}$ & $11.2 \pm 0.4^{a}$ \\
\hline $18: 1 n-7$ & $2.4 \pm 0.3^{b}$ & $2.8 \pm 0.1^{\mathrm{ab}}$ & $3.0 \pm 0.1^{\mathrm{a}}$ & $2.8 \pm 0.1^{a b}$ \\
\hline $18: 2 n-6$ & $14.9 \pm 0.8^{d}$ & $7.7 \pm 0.3^{a}$ & $10.3 \pm 0.3^{b}$ & $3.3 \pm 0.1^{c}$ \\
\hline $18: 3 n-3$ & $0.1 \pm 0.04^{c}$ & $0.3 \pm 0.05^{a}$ & $1.8 \pm 0.1^{b}$ & $0.1 \pm 0.01^{c}$ \\
\hline $20: 0$ & $0.5 \pm 0.3$ & $0.2 \pm 0.04$ & $0.5 \pm 0.1$ & $0.4 \pm 0.2$ \\
\hline $20: 1 n-9$ & $0.3 \pm 0.1^{a}$ & $0.4 \pm 0.04^{\mathrm{ac}}$ & $0.5 \pm 0.02^{b c}$ & $0.6 \pm 0.1^{b}$ \\
\hline $20: 3 n-9$ & $0.1 \pm 0.05^{c}$ & $0.3 \pm 0.00 \mathrm{ab}$ & $0.3 \pm 0.04^{\mathrm{ab}}$ & $0.2 \pm 0.04^{b c}$ \\
\hline $20: 3 n-6$ & $1.1 \pm 0.7^{c}$ & $0.6 \pm 0.04^{a b}$ & $1.2 \pm 0.3^{a b}$ & $0.9 \pm 0.2^{c}$ \\
\hline $20: 4 n-6$ & $23.0 \pm 1.2^{\mathrm{a}}$ & $21.8 \pm 0.9^{a}$ & $13.4 \pm 0.3^{b}$ & $7.9 \pm 0.1^{c}$ \\
\hline $20: 5 n-3$ & $0.1 \pm 0.04^{a}$ & $0.3 \pm 0.1^{a}$ & $2.2 \pm 0.02^{b}$ & $6.2 \pm 0.1 c$ \\
\hline 22:0 & $0.2 \pm 0.02^{a}$ & $0.3 \pm 0.01^{a}$ & $0.4 \pm 0.1^{a}$ & $0.2 \pm 0.01^{b}$ \\
\hline $22: 4 n-6$ & $1.1 \pm 0.1^{c}$ & $0.4 \pm 0.01^{\mathrm{a}}$ & $0.1 \pm 0.05^{b}$ & $0.2 \pm 0.02^{b}$ \\
\hline $22: 5 n-6$ & $2.7 \pm 0.2^{\mathrm{b}}$ & $0.4 \pm 0.05^{a}$ & $0.4 \pm 0.1^{a}$ & $0.3 \pm 0.03^{a}$ \\
\hline $22: 5 n-3$ & $0.5 \pm 0.1^{a}$ & $0.8 \pm 0.1^{a}$ & $1.7 \pm 0.1^{b}$ & $2.5 \pm 0.1^{c}$ \\
\hline $22: 6 n-3$ & $1.3 \pm 0.03^{c}$ & $6.5 \pm 0.02^{a}$ & $6.8 \pm 0.1^{a}$ & $12.8 \pm 0.4^{b}$ \\
\hline $24: 0$ & $0.6 \pm 0.03^{a}$ & $0.7 \pm 0.04^{a}$ & $0.6 \pm 0.1^{a}$ & $0.5 \pm 0.05^{b}$ \\
\hline Saturated & $43.8 \pm 0.4^{a}$ & $44.3 \pm 0.7^{a}$ & $43.2 \pm 0.4^{a}$ & $48.1 \pm 0.4^{b}$ \\
\hline Monounsaturated & $11.3 \pm 1.0^{b}$ & $16.5 \pm 1.0^{\mathrm{a}}$ & $18.6 \pm 0.3^{a}$ & $17.4 \pm 0.3^{a}$ \\
\hline$n-6$ & $42.8 \pm 1.5^{d}$ & $31.0 \pm 0.6^{a}$ & $25.4 \pm 0.4^{b}$ & $12.5 \pm 0.2^{c}$ \\
\hline$n-3$ & $2.0 \pm 0.2^{\mathrm{d}}$ & $7.9 \pm 0.2^{\mathrm{a}}$ & $12.5 \pm 0.2^{b}$ & $21.6 \pm 0.5^{c}$ \\
\hline$(n-6)+(n-3)$ & $44.8 \pm 1.7^{b}$ & $38.9 \pm 0.8^{a}$ & $37.9 \pm 0.6^{a}$ & $34.1 \pm 0.7^{c}$ \\
\hline$n-6 / n-3$ & 21.4 & 3.9 & 2.0 & 0.6 \\
\hline U1 & 12.5 & 10.8 & 12.7 & 11.9 \\
\hline
\end{tabular}

* Abbreviations are the same as in tables I and II.

in tables III-V. Compared to the control diet, all 3 experimental diets induced small changes in saturated fatty acids levels.

Monounsaturated fatty acids levels were in the same range for control, LN and SM groups. The values were lower in the SF group especially in serum since the difference with the control reached $48 \%(P<$ 0.05).
The 3 groups differed in the extent of response to dietary n-3 PUFA according to whether they were provided as precursors or derivatives.

The intake of $\alpha$-linolenic acid in amounts reaching those of linoleic acid (required levels in intake) moderately affected the fatty acid profiles. The greatest difference appeared in serum where the drop of $20: 4 n-6$ from 26 to 
Table V. Fatty acid composition of lymphocytes phospholipids after 8 weeks of dietary treatment *.

\begin{tabular}{|c|c|c|c|c|}
\hline Fatty acid & $\begin{array}{c}\text { SF diet } \\
\text { (\% of total) }\end{array}$ & $\begin{array}{c}P R \text { (control) diet } \\
(\% \text { of total) }\end{array}$ & $\begin{array}{c}\text { LN diet } \\
\text { (\% of total) }\end{array}$ & $\begin{array}{c}S M \text { diet } \\
\text { (\% of total) }\end{array}$ \\
\hline $16: 0$ & $29.6 \pm 1.1^{\mathrm{ab}}$ & $28.7 \pm 0.7^{a}$ & $28.1 \pm 0.4^{a}$ & $31.5 \pm 0.4^{b}$ \\
\hline $16: 1 n-9$ & $1.0 \pm 0.1^{b}$ & $1.0 \pm 0.05^{\mathrm{ab}}$ & $1.8 \pm 0.1 \mathrm{ac}$ & $1.6 \pm 0.2^{c}$ \\
\hline $16: 1 n-7$ & $0.7 \pm 0.1$ & $0.9 \pm 0.04$ & $0.9 \pm 0.1$ & $1.6 \pm 0.6$ \\
\hline $18: 0$ & $18.2 \pm 0.3$ & $16.8 \pm 0.2$ & $16.1 \pm 0.4$ & $17.0 \pm 1.0$ \\
\hline $18: 1 n-9$ & $10.3 \pm 1.2^{\mathrm{b}}$ & $11.8 \pm 0.3^{\mathrm{ab}}$ & $12.1 \pm 0.1^{\mathrm{ab}}$ & $12.9 \pm 0.4^{\mathrm{a}}$ \\
\hline $18: 1 n-7$ & $3.3 \pm 0.2^{b}$ & $4.0 \pm 0.1^{\mathrm{a}}$ & $3.9 \pm 0.1^{\mathrm{a}}$ & $5.4 \pm 0.2^{\mathrm{c}}$ \\
\hline $18: 2 n-6$ & $8.6 \pm 0.3^{a b}$ & $8.5 \pm 0.7^{a}$ & $7.4 \pm 0.8^{b}$ & $4.1 \pm 0.05^{\circ}$ \\
\hline $18: 3 n-3$ & ND & $0.3 \pm 0.04$ & $0.3 \pm 0.02$ & ND \\
\hline $20: 0$ & $0.3 \pm 0.1 \mathrm{ab}$ & $0.1 \pm 0.1^{\mathrm{a}}$ & $0.3 \pm 0.04 a b$ & $0.3 \pm 0.05^{b}$ \\
\hline $20: 1 n-9$ & $0.6 \pm 0.1^{b}$ & $1.2 \pm 0.04^{a}$ & $1.3 \pm 0.05^{a}$ & $1.3 \pm 0.01^{a}$ \\
\hline $20: 3 n-9$ & $0.5 \pm 0.1$ & $0.2 \pm 0.2$ & $0.3 \pm 0.1$ & $0.3 \pm 0.2$ \\
\hline $20.3 n-6$ & $1.1 \pm 0.1^{\mathrm{c}}$ & $1.2 \pm 0.1^{\mathrm{a}}$ & $1.1 \pm 0.1^{\mathrm{ac}}$ & $0.7 \pm 0.01^{b}$ \\
\hline $20: 4 n-6$ & $18.5 \pm 1.0^{\mathrm{a}}$ & $18.1 \pm 1.3^{a}$ & $19.5 \pm 0.9^{a}$ & $7.8 \pm 0.2^{b}$ \\
\hline $20: 5 n-3$ & $0.3 \pm 0.01^{b}$ & $1.4 \pm 0.4^{a}$ & $0.7 \pm 0.5^{b}$ & $7.2 \pm 0.3^{c}$ \\
\hline $22: 0$ & $0.3 \pm 0.03^{b}$ & $0.3 \pm 0.01^{\mathrm{ab}}$ & $0.3 \pm 0.03^{a b}$ & $0.4 \pm 0.04^{a}$ \\
\hline $22: 4 n-6$ & $2.5 \pm 0.2^{d}$ & $1.1 \pm 0.2^{\mathrm{a}}$ & $1.5 \pm 0.3^{b}$ & $0.1 \pm 0.1^{c}$ \\
\hline $22: 5 n-6$ & $0.6 \pm 0.1^{b}$ & ND & $0.1 \pm 0.1^{\mathrm{a}}$ & ND \\
\hline $22: 5 n-3$ & $0.04 \pm 0.04 c$ & $2.0 \pm 0.4^{a}$ & $1.6 \pm 0.4^{a}$ & $3.5 \pm 0.3^{b}$ \\
\hline $22: 6 n-3$ & $0.4 \pm 0.04 c$ & $1.6 \pm 0.05^{a}$ & $1.9 \pm 0.2^{\mathrm{a}}$ & $3.7 \pm 0.4^{b}$ \\
\hline $24: 0$ & $3.1 \pm 1.0^{\mathrm{b}}$ & $0.6 \pm 0.2^{a}$ & $0.7 \pm 0.1^{\mathrm{ac}}$ & $0.8 \pm 0.1^{c}$ \\
\hline Saturated & $51.5 \pm 0.8^{b}$ & $46.5 \pm 0.9^{a}$ & $45.5 \pm 0.8^{a}$ & $50.0 \pm 1.1^{b}$ \\
\hline Monounsaturated & $16.0 \pm 1.2^{c}$ & $18.9 \pm 0.3^{a}$ & $20.0 \pm 0.1^{a}$ & $22.7 \pm 0.6^{b}$ \\
\hline$n-6$ & $31.3 \pm 1.4^{\mathrm{a}}$ & $28.9 \pm 1.0^{\mathrm{a}}$ & $29.6 \pm 0.6^{a}$ & $12.6 \pm 0.2^{b}$ \\
\hline$n-3$ & $0.8 \pm 0.1 \mathrm{c}$ & $5.3 \pm 0.8^{a}$ & $4.6 \pm 1.2^{a}$ & $14.4 \pm 0.9 \mathrm{~b}$ \\
\hline$(n-6)+(n-3)$ & $32.1 \pm 1.3^{a}$ & $34.7 \pm 0.8^{a}$ & $34.2 \pm 0.9^{a}$ & $27.0 \pm 1.1^{b}$ \\
\hline$n-6 / n-3$ & 39.1 & 5.3 & 6.4 & 0.9 \\
\hline UI & 2.52 & 3.12 & 3.25 & 2.81 \\
\hline
\end{tabular}

* Abbreviations are the same as in tables I-III.

$15 \%$ was partly offset by the rise of n-3 PUFA (precursor and derivatives). Hence, the $n-6 / n-$ 3 ratio was equal to 2.5 (vs 8.3 in the control group). Likewise, liver PM from the LN group had a $40 \%$ lower $20: 4 n-6$ content than that from the control group. This was accompanied by an increase of 18:3n-3, 20:5n-3 and $22: 5 n-3$, but not of $22: 6 n-3$. The fatty acid composition of lymphocyte PL was not significantly influenced by LN feeding.
The intensity of the responses to dietary salmon oil and sunflower oil differed for circulating and structural lipids. Salmon oil feeding increased the incorporation of both 20:5n-3 and 22:6n-3. However, although the intake was equivalent, 20:5 and 22:6 were incorporated to a different extent. The proportion of 22:6 was higher than that of 20:5 in serum and liver PM whereas it was lower in lymphocyte PL. The precursor $18: 3 n-3$ ingested at very low levels could 
hardly be detected. Concomitantly, the incorporation of n-6 PUFA was reduced. In serum, the response to the SM diet was more pronounced for 20:4n-6 than for $18: 2 n-6$ (a 5-fold vs a 2-fold decrease), but in the liver $\mathrm{PM}$ and lymphocyte $\mathrm{PL}$, the reductions (\%) of 20:4 and 18:2 were in the same range.

Conversely, sunflower oil feeding drastically reduced n-3 PUFA in circulating and structural lipids. The parent $\alpha$-linolenic acid disappeared and long-chain derivatives accounted for less than $2 \%$ of total fatty acids. Compared with the values obtained from the control diet, the 18:2n-6 levels were enhanced by 61 and $93 \%$ in serum and liver $\mathrm{PM}$, respectively, but remained unchanged in lymphocyte PL. Bioconversion into 20:4n6 induced a relatively small increase in serum $(+17 \%)$ and did not alter the liver PM and lymphocyte PL contents.

\section{Specific binding of $L D L$ to liver plasma membrane}

The values for specific binding of porcine LDL to rat liver PM were highest in the control group (table VI). They were significantly depressed in the SM group (-31\%) and in the SF group (-21\%). However, there was no significant difference between the binding of porcine LDL to rat liver PM from either LN, SM and SF groups. Regardless of diet, there was a significant positive correlation between the receptor-mediated LDL binding to rat liver $\mathrm{PM}$ and $\mathrm{HDL}$-cholesterol $(r=$ $0.52 ; P<0.05$ ) (fig 1).

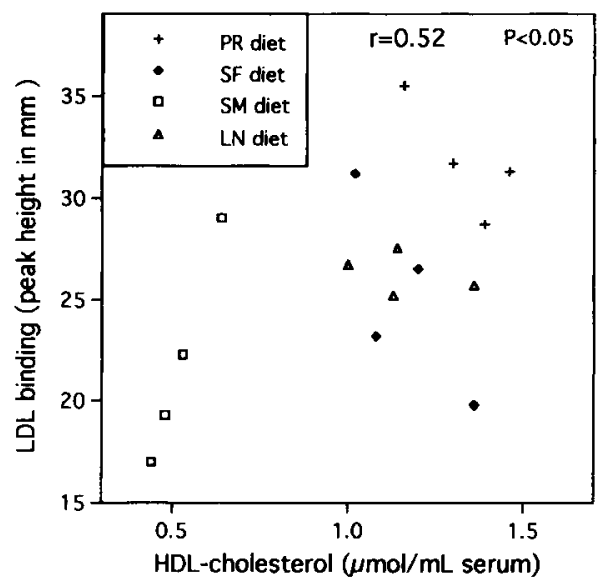

Fig 1. Correlation between HDL-cholesterol levels and specific binding of porcine LDL to liver plasma membrane preparations from rats irrespective of dietary treatments. Values from table $\mathrm{VI}$ are plotted $v s$ values from table II.

Table VI. Effects of dietary lipids on hepatic LDL receptor activity *.

\begin{tabular}{lcccc} 
LDL binding & \multicolumn{3}{c}{ Integrator peak height $(\mathrm{mm})$} \\
& SF diet & $P R$ (control) diet & LN diet & SM diet \\
\cline { 3 - 5 } & & & & \\
Total & $45.0 \pm 2.9^{\mathrm{b}}$ & $55.3 \pm 1.2^{\mathrm{a}}$ & $46.4 \pm 0.8^{\mathrm{b}}$ & $45.7 \pm 4.2^{\mathrm{b}}$ \\
Non-specific & $19.9 \pm 1.3^{\mathrm{bc}}$ & $23.5 \pm 0.6^{\mathrm{ab}}$ & $20.2 \pm 0.5^{\mathrm{bac}}$ & $23.8 \pm 1.7^{\mathrm{b}}$ \\
Specific & $25.1 \pm 2.4^{\mathrm{b}}$ & $31.8 \pm 1.4^{\mathrm{a}}$ & $26.2 \pm 0.5^{\mathrm{ab}}$ & $21.9 \pm 2.6^{\mathrm{b}}$
\end{tabular}

Solubilized rat liver plasma membranes were dot-blotted on nitrocellulose and incubated with colioidal gold conjugates of porcine LDL. The nitrocellulose was scanned with a densitometer. The specific binding was obtained by subtracting the non-specific binding from the total binding and expressed as integrator peak in $\mathrm{mm}$.

* Abbreviations are the same as in table II. 


\section{DISCUSSION}

Dietary linseed oil did not decrease the triacylglycerol and cholesterol levels in the serum and slightly increased the 20:5 and 22:6 levels in the membranes. These findings were in agreement with the works of Sanders and Roshani (1983) and Kelley et al (1993) in humans. The higher (2-fold and more) $n-6 / n-3$ ratio in serum and structural lipids than in dietary lipids suggests that a large fraction of intaken 18:3n-3 was diverted to other metabolic pathways. A fraction may have disappeared because 18:3n-3 oxidizes faster than other fatty acids (Leyton et al, 1987; Clouet et al, 1989).

Nevertheless, although a substantial fraction of 18:3n-3 was not bioconverted, the derivatives to precursor ratio of $n-6$ PUFA was lower in the serum and liver PM in the LN group than in the control group. This probably reflected the inhibition of the n-6 pathways by dietary 18:3n-3. Accordingly, the intake of required levels of linoleic acid may be insufficient to maintain the optimal fatty acid composition of membranes when diets provide too much $\alpha$-linolenic acid. The $n-6 / n-3$ ratio $(0.93)$ in dietary lipids was between those used by Barzanti et al (1986) for rats. The authors observed that the inhibition of the n-6 pathways occurred at low (0.23) but not at high (3.84) 18:2 to $18: 3$ ratios in the intake. The 20:4n-6 level was not reduced in lymphocyte $P L$, possibly because it plays a central role in cell activation during immunological processes (Meade and Mertin, 1978). Apparently, dietary long-chain n-3 PUFA only weakly depressed the conversion of linoleic acid through feed-back inhibition. Indeed, in serum as well as in membranes, the derivatives to precursor ratios were only $5-10 \%$ lower in SM than in the control group.

The lowest hepatic LDL receptor activity was found in rats fed salmon oil. The reducing effect of dietary fish oil on the specific binding of LDL to liver membranes in a heterologous system has already been observed in rats, which like ours, were fed moderate levels of fats (Roach et al, 1987a). By contrast, fish oils enhanced the LDL receptor activity in rats fed oil-enriched diets (20\% or more) both in homologous (Ventura et al, 1989) and heterologous (Sebokova et al, 1992) systems. Tripodi et al (1991) observed that dietary fish oil as compared with coconut oil increased the unsaturation of rat liver plasma membrane which bound LDL with higher affinity. In the present binding study, the differences in specific LDL binding were only due to changes affecting the receptor. Indeed, in all assays the ligand was porcine LDL which had a well-defined lipid composition and contained apo B100 as the only apolipoprotein.

The unsaturation index (which reflects global fluidity) of liver PM remained in the same range of values for all the dietary groups. This did not exclude specific effects of fatty acids located in the microenvironment of LDL receptors. It has been proposed that changes in the spacial configuration of fatty acids may alter the conformation and therefore the activity of LDL receptors (Kuo et al, 1990).

The positive linear correlation between LDL receptor activity and HDL-cholesterol might be the result of opposing effects of fish oil on hepatic LDL and HDL receptor activities (Roach et al, 1987a). As suggested by those authors, the decrease of HDLcholesterol would be related to the stimulation of hepatic HDL receptor activity.

The most striking result of the present study was the high efficiency of dietary sunflower oil for lowering fasting serum triacylglycerols whereas salmon oil had a nonsignificant reducing effect. These findings contrasted with numerous data showing that in rats, as well as in humans, dietary fish oils decrease serum triacylglycerols more efficiently than vegetable oils rich in linoleic acid (Harris et al, 1983; Balasubramaniam et 
al, 1985; Huang et al, 1986; Roach et al, 1987a; Chautan et al, 1990; Ribeiro et al, 1991; Otto et al, 1991). It is unlikely that the small excess of saturated fatty acids fed to the SM group could attenuate the hypotriglyceridemic effect of long-chain n3 PUFA. Indeed saturated fatty acids accounted for only 2.4 and $1.6 \%$ of total energy in SM and SF diets, respectively.

On the other hand, the unsaturation index of the SF diet was only slightly higher than that of the SM diet. It has been suggested that the hypotriglyceridemic effect of long chain n-3 PUFA might be related to their structure rather than to their degree of unsaturation (Harris et al, 1983). Nevertheless in rat hepatocytes, Wong et al (1985) observed that safflower oil was almost as efficient as fish oil, whereas oleic acid reversed the effect. This suggested to the authors that the reduction in triacylglycerol formation partly resulted from the diversion of PUFA into hepatic phospholipids.

In contrast, oleic acid has a stimulating effect on triacylglycerol synthesis and secretion (Davis and Boogaerts, 1982; Nossen et al, 1986) which is related to the preferential incorporation of this fatty acid into triacylglycerols (Benner et al, 1990). In humans, the intake of high levels of oleic acid may raise plasma triacylglycerol levels (Chang and Huang, 1990). The SF diet contained higher levels of oleic acid than the SM diet. However, the oleic acid content of serum and membranes was lower in the SF than in the SM group. Accordingly, the lack of available substrate for triacylglycerol synthesis could have contributed to the reduction of serum triacylglycerols.

Moreover, it is possible that the dietaryinduced changes in the membrane fatty acid composition influenced the pathway of triacylglycerol synthesis by altering the activity of associated enzymes. Actually, in microsomes from rat liver (Strum-Odin et al, 1987) or human intestinal cells (Murthy et al, 1990), the enrichment in eicosapen- taenoic acid reduced the diacylglycerol acyltransferase activity. On the other hand, oleic acid has an enhancing effect on the activity of phosphatidate phosphohydrolase bound to microsomes (Cascales et al, 1984). One should note that in a study showing that in rats, fish oil but not sunflower oil decreased plasma triacylglycerols, Balasubramaniam et al (1985) did not observe any change in the oleic acid content of liver microsomal phospholipids.

In the present study, we did not determine the fatty acid composition of microsomes. Accordingly, we cannot speculate about the relationship between the oleic acid content of membranes and the capacity of liver to synthesize triacylglycerols. Further studies are needed to examine whether dietary sunflower oil lowers both serum and liver triacylglycerols and whether the effect is associated with a reduction of triacylglycerol synthesis and with changes in the oleic acid content of liver microsomes and triacylglycerols.

\section{REFERENCES}

Balasubramaniam S, Simons LA, Chang S, Hickie JB (1985) Reduction in plasma cholesterol and increase in biliary cholesterol by a diet rich in n-3 fatty acids in the rat. J Lipid Res 26, 684-689

Barzanti V, Biagi PL, Maranesi M, Turchetto E (1986) Effect of lipids having different $n-6$ and $n-3$ fatty acid contents on some organs and subcellular structures of the rat. Prog Lipid Res 25, 221-224

Benner KG, Sasaki A, Gowen DR, Weaver A, Connor WE (1990) The differential effect of eicosapentaenoic acid and oleic acid on lipid synthesis and VLDL secretion in rabbit hepatocyte. Lipids $25,534-540$

Blond JP, Poisson JP, Lemarchal P (1978) Influence de l'acide $\alpha$-linolénique alimentaire sur la conversion des acides linoléique et $\gamma$-linolénique $[1-14 C]$ en arachidonate chez le rat in vivo. Arch int Physiol Biochim 86, 741-754

Bourre JM, François M, Youyou A et al (1989) The effects of dietary $\alpha$-linolenic acid on the composition of nerve membranes, enzymatic activity, amplitude of electrophysiological parameters, resistance to poisons and performance of learning tasks in rats. J Nutr 119, 1880-1892 
Bradford MM (1976) A rapid and sensitive method for the quantitation of microgram quantities of protein utilizing the principle of protein-dye binding. Anal Biochem 72, 248-254

Brenner RR, Peluffo RO (1969) Regulation of unsaturated fatty acids biosynthesis. 1 . Effect of unsaturated fatty acid of 18 carbons on the microsomal desaturation of linoleic acid into $\gamma$-linolenic acid. Biochim Biophys Acta 176, 471-479

Budowski P, Crawford MA (1985) $\alpha$-Linolenic acid as a regulator of the metabolism of arachidonic acid: dietary implications of the ratio, $n-6 / n-3$ fatty acids. Proc Nutr Soc 44, 221-229

Cascales C, Mangiapane EH, Brindley DN (1984) Oleic acid promotes the activation and translocation of phosphatidate phosphohydrolase from the cytosol to particulate fractions of isolated rat hepatocytes. Biochem J 213, 911-916

Chang NW, Huang PC (1990) Effects of dietary monounsaturated fatty acids on plasma lipids in humans. $J$ Lipid Res 31, 2141-2147

Chautan M, Chanussot F, Portugal H, Pauli AM, Lafont $H$ (1990) Effects of salmon oil and corn oil on plasma lipid level and hepatobiliary cholesterol metabolism in rats. Biochim Biophys Acta 1046, 40-45

Clandinin MT, Field CJ, Hargreaves K, Morson L, Zsigmond $E$ (1985) Role of diet fat in subcellular structure and function. Can J Physiol Pharmaco/63, 546556

Clouet P, Niot I, Bezard J (1989) Pathway of $\alpha$-linolenic acid through the mitochondrial outer membrane in the rat liver and influence on the rate of oxidation. Comparison with linoleic and oleic acids. Biochem $J 263$, 867-873

Cunnane SC, Chen ZY, Yang J, Liede AC, Hamadeh M, Crawford MA (1991) $\alpha$-Linolenic acid in humans: direct functional role or dietary precursor? Nutrition 7, 437-439

Davis RA, Boogaerts JR (1982) Intrahepatic assembly of very low density lipoproteins. Effect of fatty acids on triacylglycerol and apolipoprotein synthesis. $J$ Biol Chem 257, 10908-10913

Durand G, Pascal G, Vodovar N, Gounelle de Pontanel $H$ (1978) Prévention de l'hypercholestérolémie chez le rat : effets comparés d'huiles végétales et d'huiles de poisson. Med Nut 14, 195-204

Epping RJ, Bygrave F (1984) A procedure for the rapid isolation from rat liver of plasma membrane vesicles exhibiting $\mathrm{Ca}^{2+-t r a n s p o r t}$ and $\mathrm{Ca}^{2+-}$-ATPase activities. Biochem J 223, 733-745

Folch J, Lees M, Sloane Stanley GH (1957) A simple method for the isolation and purification of total lipids from animal tissues. J Biol Chem 226, 497-509

Frémont L, Gozzelino MT, Bosseau AF (1993) Effects of sugar-beet fiber feeding on serum lipids and binding of low-density lipoproteins to liver membranes in growing pigs. Am J Clin Nutr 57, 524-532
Goodnight SH, Harris WS, Connor WE, Illingworth DR (1982) Polyunsaturated fatty acids, hyperlipidemia and thrombosis. Arteriosclerosis 2, 87-113

Harris WS, Connor WE, McMurry MP (1983) The comparative reductions of the plasma lipids and lipoproteins by dietary polyunsaturated fats: salmon oil versus vegetable oils. Metabolism 32, 179-184

Havel RJ, Eder HA, Bragdon JH (1955) The distribution and chemical composition of ultracentrifugally separated lipoproteins in human serum. $J$ Clin invest 34, 1345-1353

Holman RT (1986) Nutritional and biochemical evidence of acyl interaction with respect to essential polyunsaturated fatty acids. Prog Lipid Res 25, 29-39

Huang YS, Nassar RA, Horrobin DF (1986) Changes of plasma lipids and long-chain $n-3$ and $n-6$ fatty acids in plasma, liver, heart and kidney phospholipids of rats fed variable levels of fish oil with or without cholesterol supplementation. Biochim Biophys Acta 879, 22-27

Juaneda P, Rocquelin G (1985) Rapid and convenient separation of phospholipids and non-phosphorus lipids from rat heart using silica cartridges. Lipids $20,40-41$

Kelley DS, Nelson GJ, Love JE et al (1993) Dietary $\alpha$ linolenic alters tissue fatty acid composition, but not blood lipids, lipoproteins or coagulation status in humans. Lipids 28, 533-537

Kuo P, Weinfeld M, Loscalzo J (1990) Effect of membrane fatty acid composition on LDL metabolism in Hep G2 hepatocytes. Biochemistry 29, 6626-6632

Law A, Scott J (1990) A cross-species comparison of the apolipoprotein $B$ domain that binds to the LDL receptor. J Lipid Res 31, 1109-1120

Leyton J, Drury PJ, Crawford MA (1987) Differential oxidation of saturated and unsaturated fatty acids in Vivo in the rat. Br J Nutr 57, 383-393

Maggi FM, Catapano AL (1987) A dot-blot assay for the low density lipoprotein receptor. J Lipid Res 28,108 112

Meade CJ, Mertin K (1978) Fatty acids and immunity Adv Lipid Res 16, 127-165

Murphy MG (1990) Dietary fatty acids and membrane protein function. J Nutr Biochem 1, 68-79

Murthy S, Albright E, Mathur SN, Field J (1990) Effect of eicosapentaenoic acid on triacyglycerol transport in Ca Co-2 cells. Biochim Biophys Acta 1045, 147-155

Nossen JO, Rustan AC, Gloppestad SH, Malbakken S, Drevon CA (1986) Eicosapentaenoic acid inhibits synthesis and secretion of triacylglycerols by cultured rat hepatocytes. Biochim Biophys Acta 879 , 56-65

Otto DA, Tsai CE, Baltzell JK, Wooten JT (1991) Apparent inhibition of hepatic triacylglycerol secretion, independent of synthesis in high-fat fish oil-fed rats: role for insulin. Biochim Biophys Acta 1082, 37-48 
Ribeiro A, Mangeney M, Cardot P et al (1991) Effect of dietary fish oil and corn oil on lipid metabolism and apolipoprotein gene expression by rat liver. Eur $J$ Biochem 196, 499-507

Roach PD, Kambouris AM, Trumble RP, Topping DL, Nestel PJ (1987a) The effects of dietary fish oit on hepatic high density and low density lipoprotein receptor activities in the rat. FEBS Lett 222, 159-162

Roach PD, Zollinger M, Noel SP (1987b) Detection of the low density lipoprotein (LDL) receptor on nitrocellulose paper with colloidal gold-LDL conjugates. J Lipid Res 28, 1515-1521

Sanders TAB, Roshani F (1983) The influence of different types of $\omega 3$ polyunsaturated fatty acids on blood lipids and platelet function in healthy volunteers. Clin Sci $64,91-99$

Sebokova E, Klimes I, Hermann M et al (1992) Fish oil modifies lipid composition and liver LDL receptor activity in hypertriglyceridemic rats. Diab Nutr Metab $5,249-257$

Sjoblom L, Eklund A (1989) Determination of $\mathrm{HDL}_{2}$ cholesterol by precipitation with dextran sulfate. Lipids 24, 532-534

Strum-Odin R, Adkins-Finke B, Blake WL, Phinney SD, Clarke SD (1987) Modification of fatty acid compo- sition of membrane phospholipid in hepatocyte monolayer with n-3, n-6 and n-9 fatty acids and its relationship to triacylglycerol production. Biochim Biophys Acta 921, 378-391

Tripodi A, Loria P, Dilengite Carulli N (1991) Effect of fish oil and coconut oil diet on the LDL receptor activity of rat liver plasma membranes. Biochim Biophys Acta 1083, 298-304

Ventura MA, Woollett LA, Spady DK (1989) Dietary fish oil stimulates hepatic low density lipoprotein transport in the rat. J Clin Invest 84, 528-537

Wahle KWJ (1983) Fatty acid modification and membrane lipids. Proc Nutr Soc 42, 273-287

Warmick CR, Cheung MC, Albers JJ (1979) Comparison of current methods for high-density lipoprotein cholesterol quantification. Clin Chem 25, 596-604

Wong S, Reardon M, Nestel P (1985) Reduced triglyceride formation from long-chain polyenic fatty acids in rat hepatocytes. Metabolism 34, 900-905

Wong SH, Nestel PJ, Trimble RP, Storer GB, Illman RJ, Topping DL (1982) The adaptative effects of dietary fish and sunflower oil on lipid and lipoprotein metabolism in perfused rat liver. Biochim Biophys Acta 792, 103-109 